\title{
Cystine/Glutamate Transporter Protein
}

National Cancer Institute

\section{Source}

National Cancer Institute. Cystine/Glutamate Transporter Protein. NCI Thesaurus. Code C61130.

Cystine/g lutamate transporter protein ( $501 \mathrm{aa}, \sim 55 \mathrm{kDa}$ ) is encoded by the human SLC7A11 gene. This protein is involved in the exchange of anionic amino acids and has a high specificity for anionic forms of cystine and glutamate. The protein has been identified as a method of entry utilized by the Karposi's sarcoma herpesvirus to gain entry into the cell. The virus plays an essential role in the pathogenesis of Karposi's sarcoma and certain types of lymphoma. 